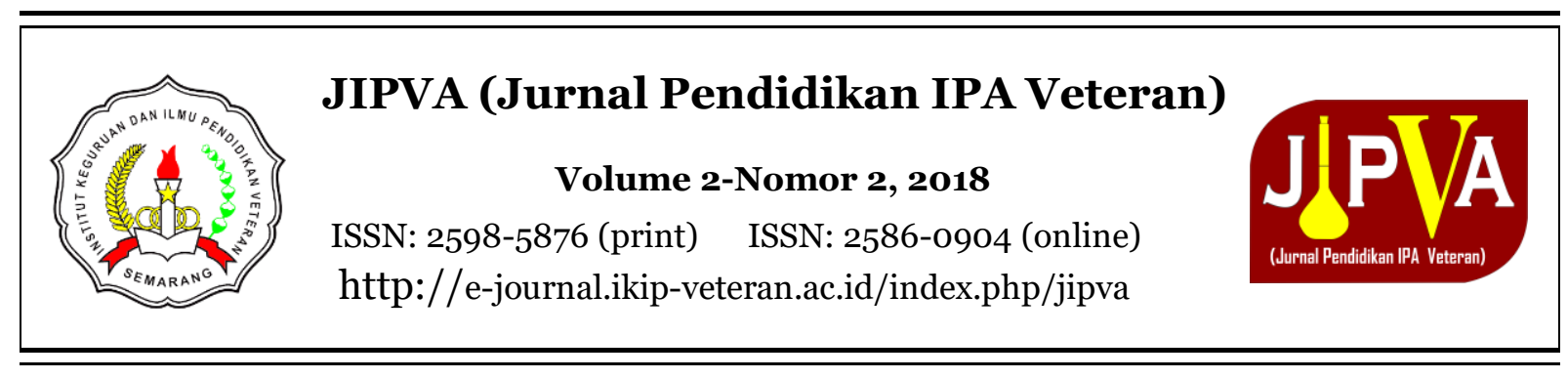

\title{
Rancang Bangun Simulasi Komputer untuk Pembelajaran Fisika pada Topik Selektor Kecepatan dengan Metode Numerik Euler
}

\author{
Hari Anggit Cahyo Wibowo \\ Program Studi Pendidikan Fisika, STKIP Al-Hikmah, Surabaya, Indonesia \\ *Email: anggitpm2013@gmail.com
}

Received: 17 September 2018; Revised:20 Oktober 2018; Accepted:22 Oktober 2018

\begin{abstract}
Abstrak
Salah satu kesulitan dalam pembelajaran fisika adalah sedikitnya alat peraga atau praktikum yang mampu menggambarkan secara nyata fenomena fisis. Topik tersebut misalnya medan listrik dan medan magnet, khususnya pada topik selektor kecepatan pada spektrometer. Tujuan penelitian ini adalah mengembangkan simulasi komputer untuk pembelajaran Fisika pada topik gerak partikel dalam selektor kecepatan. Penelitian ini menggunakan model pengembangan sikuensial linier. Model pengembangan perangkat ini dipilih karena sangat mudah diaplikasikan, serta dapat dengan mudah dilakukan verifikasi dan testing pada setiap tahapnya. Pengembangan ini menggunakan perangkat lunak Microsoft VBA Excel. Metode numerik yang dipilih adalah metode numerik Euler dengan menyelesaikan secara numerik persamaan differensial orde dua persamaan gerak partikel tersebut. Hasil pengembangan simulasi ini didapatkan tingkat kesalahan setiap titik pada metode numerik dan analitik ratarata yaitu sebesar $0.52 \%$. Hasil validasi simulasi tersebut mendapatkan nilai rata-rata 3,38 yang berdasarkan referensi nilai tersebut tergolong layak, sehingga pengembangan simulasi ini dapat disimpulkan memiliki arti fisis gerak partikel dalam selektor kecepatan.
\end{abstract}

Kata Kunci: Metode Numerik Euler, Rancang Bangun, Simulasi, Selektor Kecepatan.

\section{Design of Computer Simulation for Physics Learning on Velocity Selector Topic Using Euler Numerical Method}

\begin{abstract}
One of the difficulties in learning physics is the less of teaching media or practicums that able to describe phenomena on the electric and magnetizm topic clearly. For example the topic is electric and magnetic field, particularly velocity selector in spectrometer. The aim of this research is to develop simulation for physics learning in this topic is expected as a solution. This research use sequential linear model development. The advantage of this model is simple to understand, each phase has specific deliverables and a review process. We use Microsoft VBA Excel to develop simulation. The Euler numerical method is used to solve the secondorder differential equations of the particle's motion. The error rate of each point in the numerical and analytical method is calculated and results the average error rate $0.52 \%$. Validation result of this simulation gets an average score 3.38. Based on the reference, that score is concidered to be reasonable, so the development of this simulation can be concluded as a good physical interpretation
\end{abstract}

Keywords: Euler Numerical Method, Design, Simulation, Velocity Selector. 
How to Cite: Wibowo, H. (2018). Rancang Bangun Simulasi Komputer untuk Pembelajaran Fisika pada Topik Selektor Kecepatan dengan Metode Numerik Euler. JIPVA (Jurnal Pendidikan IPA Veteran), 2(2), 141-148. doi:10.31331/jipva.v2i2.684

\section{PENDAHULUAN}

Beberapa materi dalam pelajaran fisika di sekolah dapat dipahami dengan mudah oleh siswa melalui kegiatan praktikum dan demonstrasi (Anugrah, Serevina, \& Nasbey, 2015). Kegiatan praktikum dan demonstrasi akan jauh lebih bermakna apabila dikembangkan pula media pembelajaran yang relevan dengan topik tertentu. Penggunaan media dalam pembelajaran Fisika terbukti memberikan pengaruh yang signifikan terhadap hasil pembelajaran tersebut (Supardi \& dkk, 2012). Media tersebut dapat berupa animasi dalam jaringan, media kreatif manual, bahkan dengan memanfaatkan sosial media (Irwandani \& Juariyah, 2016; Nugroho, Raharjo, \& Wahyuningsih, 2013; Sakti, Puspasari, \& Risdianto, 2012; Sudibjo, 2013; Wahyudin, Sutikno, \& Isa, 2010).

Praktikum dan demonstrasi memberikan kesempatan kepada siswa untuk lebih memahami fenomena yang terjadi. Hal ini dikarenakan siswa terlibat langsung dalam pembelajaran. Namun kenyataannya, tidak semua fenomena fisika yang dipelajari di tingkat sekolah menengah dapat ditunjukkan dalam bentuk praktikum maupun demonstrasi.

Salah satu topik fisika dasar yang cukup sulit untuk dibuat perangkat praktikum atau demonstrasi adalah materi medan listrik dan medan magnet. Hasil penelitian menunjukkan bahwa ada $71 \%$ peserta didik mengalami miskonsepsi pada materi kelistrikan (Prasetyono, 2017). Medan listrik dan medan magnet merupakan besaran yang tidak dapat dilihat secara visual. Begitu pula pada sub topik selektor kecepatan, sangat sulit untuk dibuat set alat praktikumnya.

Animasi menjadi salah satu solusi dalam mengurangi miskonsepsi yang diajarkan dari fenomena yang sesungguhnya. Namun, animasi dalam fisika juga memiliki kelemahan, yaitu hanya menunjukkan proses visual terjadinya suatu fenomena yang mengabaikan unsur-unsur fisis yang ada. Bahkan peneliti lain mengungkapkan justru dengan penggunaan animasi peserta didik mengalami miskonsepsi pemahaman (Kustanti, 2013).

Solusi lain yang dapat ditawarkan berikutnya dalam rangka menutup kelemahan tersebut yaitu dengan menggunakan media simulasi. Simulasi tidak hanya menggambarkan proses tetapi juga memiliki unsur fisis yang cukup dekat dengan fenomena tersebut. Dengan demikian simulasi menjadi solusi alternatif selain praktikum.

Simulasi komputer merupakan salah satu media pembelajaran yang mampu merepresentasikan fenomena fisika secara ideal, aman (untuk eksperimen berbahaya), murah dan melengkapi keterbatasan laboratorium di sekolah (Sarabando, Cravino, \& Soares, 2014). Pembuatan simulasi komputer tentu tidak terlepas dari kebutuhan akan perangkat lunak (software). Software yang dimaksud setidaknya merupakan software yang mudah dioperasikan dan tentunya tidak asing bagi para pendidik Fisika. Microsoft Visual Basic for Application (VBA) yang terdapat dalam salah satu fitur Microsoft Excel merupakan salah satu software yang dapat digunakan untuk membuat simulasi fenomena fisika. Microsoft Excel yang selama ini sudah 
sangat akrab dikalangan akademis dalam hal ini para pendidik, sehingga penggunaan ini diharapkan menjadi salah satu solusi kemudahan dalam membuat simulasi fenomena fisika khususnya untuk topik lintasan partikel yang bergerak dalam selektor kecepatan.

Media pembelajaran yang dirancang dengan baik akan membantu peserta didik untuk lebih mudah memahami materi yang disampaikan (Muhson, 2010). Bagi pendidik, media pembelajaran sangat bermanfaat untuk membantu dan mempermudah mencapai tujuan pembelajaran (Wicaksono \& Hakim, 2011). Penelitian lain tentang media pembelajaran juga menyatakan bahwa apabila media pembelajaran yang digunakan oleh pendidik bersifat konvensional akan cenderung membuat peserta didik kurang termotivasi dan kurang antusias (Andiyana \& Muchlas, 2015).

Selektor kecepatan memiliki fungsi diantaranya untuk mengetahui kecepatan suatu partikel yang ditembakkan (Serway \& Jewett, 2014). Selektor kecepatan merupakan salah satu bagian dari spektrometer massa yang memiliki fungsi akhir untuk menentukan massa dari suatu partikel. Beberapa prinsip dasar fisika digunakan dalam alat ini, diantaranya adalah konsep medan listrik dan medan magnet serta konsep mekanika gerak partikel yang dipengaruhi oleh gaya konstan.

Sebuah partikel yang memiliki muatan dan dilewatkan dalam medan listrik akan mengalami gaya listrik yang besarnya sebanding dengan kuat medan listrik dan besar muatan. Muatan listrik merupakan besaran skalar sedangkan medan listrik merupakan besaran vektor (Serway \& Jewett, 2014).

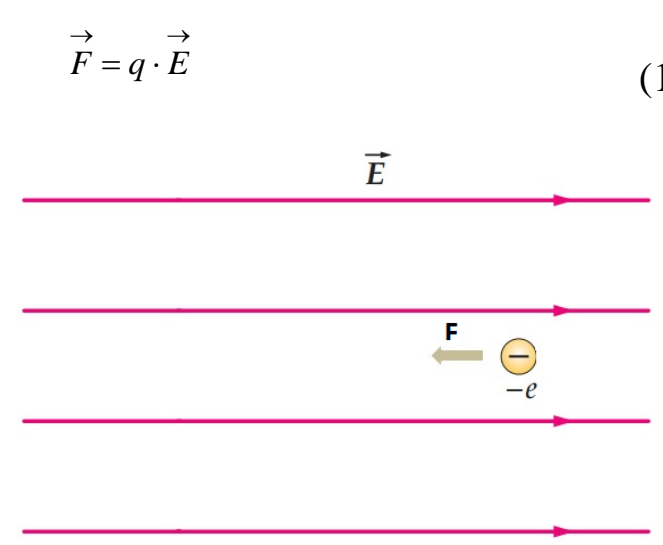

Gambar 1. Muatan e- mengalami gaya yang ditimbulkan oleh medan magnet

Gambar 1 merupakan ilustrasi dari sebuah elektron yang berada dalam pengaruh medan listrik searah sumbu $\mathrm{X}$ positif, maka elektron tersebut mengalami gaya listrik yang searah dengan sumbu $\mathrm{X}$ negatif.

Apabila sebuah partikel bergerak dengan kecepatan tertentu dalam pengaruh medan magnet, maka partikel tersebut akan mengalami gaya magnet dengan nilai sebesar perkalian cross product dari kecepatan dan medan magnet (Serway \& Jewett, 2014). Gambar 2 menunjukkan bagaimana partikel akan bergerak menurut lintasan yang digambarkan sesuai dengan arah gaya magnet yang selalu berubah karena perkalian silang tersebut.

$$
\vec{F}=q \cdot \vec{v} \times \vec{B}
$$

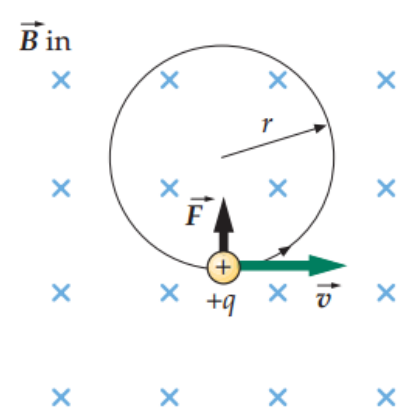

Gambar 2. Muatan +q Mengalami Gaya Magnet 
Pada selektor kecepatan dalam satu ruangan terdapat medan listrik dan medan magnet yang memiliki arah saling tegak lurus, dengan demikian partikel yang melewati selektor kecepatan tersebut mengalami dua gaya secara bersamaan, yaitu gaya listrik oleh medan listrik dan gaya magnet oleh medan magnet.

Perbedaan besar gaya yang dialami oleh partikel sangat menentukan apakah partikel tersebut dapat keluar dari selektor kecepatan ataukah tidak. Hal ini dikarenakan hanya partikel yang memiliki resultan gaya nol atau mendekati nol dengan rentang tertentu saja yang dapat keluar. Apabila resultan gaya adalah nol, maka sesuai ilustrasi pada Gambar 3. Partikel tersebut akan bergerak lurus dan dapat keluar dari selektor kecepatan.

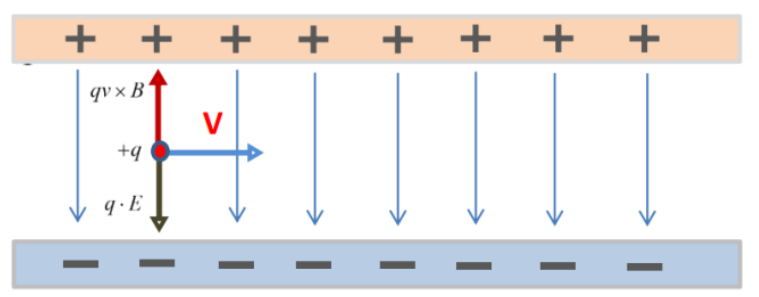

Gambar 3. Partikel dalam Selektor

Kecepatan

Salah satu dari sekian banyak media pembelajaran Fisika berbasis digital adalah simulasi Fisika. Simulasi Fisika berbeda dengan animasi Fisika. Animasi Fisika memperlihatkan gambar fenomena fisis dengan gerakan-gerakan dan tampilan yang dibuat mirip dengan aslinya. Namun pada animasi Fisika tidak memperhatikan nilainilai fisis yang sesuai dengan realita. Sebagai contoh pada animasi gerak parabola, pengembang hanya membuat fenomena gerakan benda mirip dengan gerak parabola pada aslinya. Faktor berapa gaya gravitasi, sudut kecepatan awal yang sesuai realita tidak terlalu diperhatikan. Sedangkan simulasi memperhatikan secara detail nilai-nilai fisis yang seharusnya ada dan sesuai realita.

Pembelajaran dengan memanfaatkan simulasi Fisika terbukti memberikan peningkatan terhadap minat dan penguasaan konsep (Saregar, 2016). Selain peningkatan minat dan penguasaan konsep penelitian lain juga menyebutkan bahwa penggunaan simulasi dalam pembelajaran Fisika berpengaruh terhadap kemampuan berpikir logis peserta didik (Purwanto, 2015). Dengan demikian, tujuan dari penelitian ini yaitu mengembangkan simulasi komputer untuk pembelajaran Fisika pada topik gerak partikel dalam selektor kecepatan. Dengan demikian, tujuan penelitian ini adalah mengembangkan simulasi komputer untuk pembelajaran Fisika pada topik gerak partikel dalam selektor kecepatan. Penelitian ini menggunakan model pengembangan sikuensial linier.

\section{METODE}

Pengembangan simulasi topik Fisika selektor kecepatan dilakukan dengan dua metode, yaitu metode numerik Euler (Setiawan, 2006) dan metode analitik. Hasil dari kedua metode tersebut akan dihitung rata-rata kesalahan yang ada pada setiap titik.

Besaran-besaran fisis yang telah dipilih dan ditentukan dalam simulasi ini diantaranya medan magnet 0,3 Tesla, kecepatan partikel saat masuk ke dalam selektor kecepatan $7 \times 104 \mathrm{~m} / \mathrm{s}$, besar muatan $+q=1,6 \times 10^{-19} \mathrm{C}$, dan massa muatan $+\mathrm{q}=1,6 \times 10^{-27} \mathrm{~kg}$.

Pemilihan nilai ini dilakukan untuk melihat pengaruh perubahan variabel medan listrik, sehingga perubahan lintasan partikel dapat diketahui, meskipun pada prinsipnya semua variabel dapat diubah dan disesuaikan. Rentang nilai medan listrik yang dipilih yaitu 10000-30000 V/m. 
Hasil dari pengembangan simulasi ini kemudian dibandingkan dengan hasil simulasi dengan metode analitik. Perbandingan kedua hasil tersebut akan menentukan apakah metode numerik Euler dapat diterapkan dalam pembuatan simulasi dengan tingkat kesalahan yang diterima.

\section{Jenis Penelitian}

Penelitian ini menggunakan model pengembangan sistem sikuensial linier. Model pengembangan ini dipilih karena bersifat sistematis dan berurutan (Marianda, Johar, \& Risdianto, 2014).

\section{Waktu dan Tempat Penelitian}

Penelitian dilakukan di STKIP Al Hikmah Surabaya selama 1 semester pada semester genap tahun ajaran 2017/2018.

\section{Target/Subjek Penelitian}

Target/Subjek dalam penelitian ini adalah program simulasi komputer untuk pembelajaran fisika pada topik selektor kecepatan dengan metode numerik euler.

\section{Prosedur}

Model pengembangan ini terdiri dari beberapa tahap yaitu: 1)rekayasa dan pemodelan sistem; 2) analisis; 3) pengkodean; 4) pengujian sistem; dan 5) operasi dan pemeliharaan.

Rekayasa dan pemodelan sistem yaitu langkah awal berupa identifikasi permasalahan yang ada di lapangan. Masalah tersebut pada pembelajaran fisika di lingkungan sekolah diobservasi secara mendalam. Selanjutnya pada tahap kedua yaitu analisis terhadap data hasil identifikasi masalah yang diperoleh dari tahap sebelumnya. Pada tahap ketiga, rancang bangun sistem dikerjakan. Pengkodean terhadap sistem yang telah dibuat dilakukan pada tahap tiga. Pada penelitian ini dilakukan pengkodean sistem simulasi fisika dengan menggunakan bahasa pemrograman VBA Excel. Pengujian sistem dilakukan dengan dua cara, pertama pengujian nilai ralat sistem, dengan cara membandingkan nilai numerik dengan nilai analitik dan kedua pengujian dilakukan dengan melakukan validasi terhadap simulasi yang dikembangkan. Validator program ini adalah sebanyak dua orang dosen Pendidikan Fisika. Tahap selanjutnya yaitu operasi dan pemeliharaan sistem secara nyata.

\section{Data}

Data pada penelitian ini merupakan angka-angka numerik setiap titik posisi partikel yang disimulasikan. Selain data numerik tersebut juga dibuat data analitik pada masing-masing titik yang nanti akan dibandingkan dengan data numerik.

\section{Teknik Analisis Data}

Analisis data dilakukan dengan menggunakan metode statistik sederhana, yaitu dengan membandingkan nilai numerik pada masing-masing titik posisi partikel dengan nilai analitik. Berdasarkan hasil perbandingan tersebut kemudian diperoleh nilai ralat. Apabila nilai ralat dibawah 5\% maka dapat dikatakan hasil pengembangan simulasi tersebut dapat diterima.

\section{HASIL DAN PEMBAHASAN}

Hasil akhir pengembangan simulasi ini berupa grafik yang secara aktif menunjukkan arah dan kecepatan gerak partikel yang memiliki kecepatan tertentu dan melewati medan listrik dengan nilai sudah ditentukan pula. Tampilan simulasi seperti pada Gambar 4. 


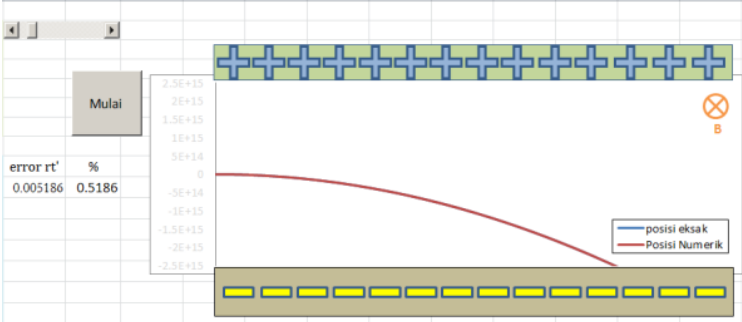

Gambar 4. Tampilan Muka Program

Gambar 4 menujukkan tampilan muka dari program simulasi yang dikembangkan menggunakan VBA Excel. Grafik tersebut menunjukkan arah dan kecepatan gerak partikel. Hasil tampilan data simulasi ditunjukkan Gambar 5 berikut.

\begin{tabular}{|c|c|c|c|c|}
\hline $\begin{aligned} B & = \\
V x & = \\
\text { muatan } q & =\end{aligned}$ & $\begin{array}{l}0.3 \\
70000 \\
1.6 \mathrm{E}-19\end{array}$ & $\begin{array}{l}\text { Tesla } \\
m / s \\
\mathrm{C}\end{array}$ & massa $(m)=$ & $1.67 \mathrm{E}-27$ \\
\hline gnet & $F m=$ & $3 \mathrm{E}-15$ & $F r=$ & -15 \\
\hline aya listrik & $F_{e}=$ & $2 \mathrm{E}-15$ & $\mathrm{Fr} / \mathrm{m}=$ & $8.527 E+11$ \\
\hline rxeksak & ryeksak & rx num & ry num & Error \\
\hline 0 & 0 & 0 & 0 & \\
\hline 70000 & $-4.31 \mathrm{E}+11$ & 70000 & $-4.32 \mathrm{E}+11$ & 0.0999 \\
\hline 140000 & $-1.72 \mathrm{E}+12$ & $1 E+05$ & $-1.73 \mathrm{E}+12$ & 0.049975 \\
\hline 210000 & $-3.88 \mathrm{E}+12$ & $2 \mathrm{E}+05$ & $-3.88 \mathrm{E}+12$ & 0.033322 \\
\hline 280000 & $-6.9 E+12$ & $3 E+05$ & $-6.9 E+12$ & 0.024994 \\
\hline 350000 & $-1.08 \mathrm{E}+13$ & $4 E+05$ & $-1.08 E+13$ & 0.019996 \\
\hline
\end{tabular}

Gambar 5. Tampilan Muka Program Bagian Data Rekam Posisi Pergerakan Partikel dan Nilai Ralatnya

Persamaan gaya dalam gerak partikel di dalam selektor kecepatan pada arah sumbu $\mathrm{Y}$ oleh pengaruh medan listrik dan medan magnet yaitu:

$$
\begin{aligned}
& \sum F_{y}=\vec{F}_{m}+\vec{F}_{e} \\
& \sum F_{y}=q \cdot \vec{v} \times \vec{B}+q \cdot \vec{E}
\end{aligned}
$$

Persamaan differensial orde dua dari gerak partikel tersebut adalah :

$$
\begin{aligned}
& \sum F_{y}=m \frac{d^{2} y}{d t^{2}} \\
& \frac{d^{2} y}{d t^{2}}=\frac{\sum F_{y}}{m}
\end{aligned}
$$

Solusi numerik metode Euler dalam persamaan ini diungkapkan dalam tabel sebagai berikut :

Tabel 1. Solusi Numerik Lintasan Partikel

\begin{tabular}{cccc}
\multicolumn{4}{c}{ sepanjang sumbu $y$} \\
\hline I & $\mathrm{y}(\mathrm{i})$ & $\mathrm{y}^{\prime}(\mathrm{i})$ & $\mathrm{y}^{\prime \prime}(\mathrm{i})$ \\
\hline 0 & 0 & 0 & $\mathrm{~d}^{2} \mathrm{y} / \mathrm{dt}^{2}$ \\
\hline 0.1 & $\mathrm{y}(0)+0.1^{*} \mathrm{y}^{\prime}(1)$ & $\mathrm{y}^{\prime}(0)+0.1^{*} \mathrm{y}^{\prime \prime}(0)$ & $\mathrm{d}^{2} \mathrm{y} / \mathrm{dt}^{2}$ \\
\hline 0.2 & $\mathrm{y}(1)+0.1^{*} \mathrm{y}^{\prime}(2)$ & $\mathrm{y}^{\prime}(1)+0.1^{*} \mathrm{y}^{\prime \prime}(1)$ & $\mathrm{d}^{2} \mathrm{y} / \mathrm{dt}^{2}$ \\
\hline 0.3 & $\mathrm{y}(2)+0.1^{*} \mathrm{y}^{\prime}(3)$ & $\mathrm{y}^{\prime}(2)+0.1^{*} \mathrm{y}^{\prime \prime}(2)$ & $\mathrm{d}^{2} \mathrm{y} / \mathrm{dt}^{2}$ \\
\hline$\cdots$ & $\ldots$ & $\cdots$ & $\cdots$ \\
\hline
\end{tabular}

Persamaan gerak partikel dalam selektor kecepatan dalam arah sumbu X sebagai berikut:

$$
\begin{aligned}
& \sum F_{x}=m \frac{d^{2} x}{d t^{2}} \\
& \frac{d^{2} x}{d t^{2}}=\frac{\sum F_{x}}{m}
\end{aligned}
$$

Tabel 2. Solusi Numerik Lintasan Partikel sepanjang sumbu $x$

\begin{tabular}{cccc}
\hline I & $\mathrm{x}(\mathrm{i})$ & $\mathrm{x}^{\prime}(\mathrm{i})$ & $\mathrm{x}^{\prime \prime}(\mathrm{i})$ \\
\hline 0 & 0 & $\mathrm{x}^{\prime}(0)=\mathrm{k}$ (0nstan & 0 \\
\hline 0.1 & $\mathrm{x}(0)+0.1^{*} \mathrm{x}^{\prime}(1)$ & $\mathrm{x}^{\prime}(0)+0.1^{*} \mathrm{x}^{\prime \prime}(0)$ & 0 \\
\hline 0.2 & $\mathrm{x}(1)+0.1^{*} \mathrm{x}^{\prime}(2)$ & $\mathrm{x}^{\prime}(1)+0.1^{*} \mathrm{x}^{\prime \prime}(1)$ & 0 \\
\hline 0.3 & $\mathrm{x}(2)+0.1^{*} \mathrm{x}^{\prime}(3)$ & $\mathrm{x}^{\prime}(2)+0.1^{*} \mathrm{x}^{\prime \prime}(2)$ & 0 \\
\hline$\ldots$ & $\ldots$ & $\ldots$ & $\ldots$ \\
\hline
\end{tabular}


Simulasi selektor kecepatan yang dibuat dengan metode numerik Euler dapat menggambarkan secara visual pergerakan partikel. Nilai kesalahan (error) rata-rata yang diperoleh sebesar $0,52 \%$. Adapun perbedaan lintasan dari hasil numerik dan analitik, hampir tidak terdapat perbedaan visual yang signifikan. Hasil validasi program simulasi ini mendapatkan nilai rata-rata 3,38. Berdasarkan kriteria kelayakan yang diadaptasi dari referensi nilai validasi tersebut masuk pada kategori layak (Arikunto, 2010).

\section{SIMPULAN DAN SARAN}

\section{Simpulan}

Pengembangan simulasi komputer untuk pembelajaran Fisika pada Topik Selektor Kecepatan dapat dibuat dengan menggunakan Microsoft Visual Basic for Application dalam Microsoft Excel. Simulasi yang berhasil dikembangkan mampu membandingkan antara metode numerik dan analitik nilai titik-titik lintasan partikel dengan nilai error $0.52 \%$ serta masuk dalam kategori layak. Sehingga dapat disimpulkan bahwa simulasi ini dapat menggambarkan serta memberikan arti fisis gerak partikel dalam selektor kecepatan.

\section{Saran}

Pengembangan simulasi pembelajaran Fisika sangat diperlukan untuk memperkuat pemahaman terhadap konsep-konsep fisika yang abstrak. Para pengembang di masa yang akan datang dapat mengembangkan simulasi yang dapat diakses secara mudah dan luas misalnya dengan menggunakan perangkat telepon genggam (handphone).

\section{DAFTAR PUSTAKA}

Andiyana A., \& Muchlas M. (2015). Pengembangan media pembelajaran fisika berbasis komputer menggunakan komik animasi untuk siswa SMP. In In Prosiding Seminar Nasional ALFA IV. (pp. 309-312). Yogyakarta.

Anugrah, M. I., Serevina, V., \& Nasbey, H. (2015). Pengembangan alat praktikum medan magnet sebagai media pembelajaran Fisika SMA. In Prosiding Seminar Nasional Fisika (EJournal) SNF2015 (pp. 125-130). Jakarta.

Arikunto S. (2010). Prosedur penelitian (Revisi). Jakarta: Rineka Cipta.

Irwandani, I., \& Juariyah, S. (2016). Pengembangan media pembelajaran berupa komik fisika berbantuan sosial media instagram sebagai alternatif pembelajaran. Jurnal Ilmiah Pendidikan Fisika Al-Biruni, 5(1), 3342.

https://doi.org/10.24042/jpifalbiruni.v5 i1.103

Kustanti, R. N. T. (2013). Pemahaman konsep siswa setelah menggunakan media pembelajaran animasi Fisika yang tidak sesuai Fisika. Berkala Fisika Indonesia, 5(1), 20-24.

Marianda, G., Johar, A., \& Risdianto, E. (2014). Rancang bangun media pembelajaran berbasis multimedia interaktif konsep gaya pada mata pelajaran Fisika SMP kelas VIII. Jurnal Rekursif, 2(2), 112-120.

Muhson, A. (2010). Rancang bangun media pembelajaran berbasis multimedia interaktif konsep gaya pada mata pelajaran Fisika SMP kelas VIII. Jurnal Pendidikan Akuntansi Indonesia, $\quad 8(2), \quad 1-10$. https://doi.org/10.21831/JPAI.V8I2.94 9 
Nugroho, A. P., Raharjo, T., \& Wahyuningsih, D. (2013). Pengembangan media pembelajaran Fisika menggunakan permainan ular tangga ditinjau dari motivasi belajar siswa kelas VIII Materi Gaya. Jurnal Pendidikan Fisika, 1(1), 11-18.

Prasetyono, R. N. (2017). Miskonsepsi Mahasiswa Teknik Informatika pada Materi Kelistrikan. JIPVA (Jurnal Pendidikan IPA Veteran), 1(1), 62-71.

Purwanto, A. (2015). Sistematika Berfikir Logis Menggunakan Media Simulasi Fisika pada Siswa Kelas X di SMA Negeri 6 Kota Bengkulu. In Prosiding Seminar Nasional Fisika 2015 (pp. 8388). Jakarta.

Sakti, I., Puspasari, Y. M., \& Risdianto, E. (2012). Pengaruh model pembalajaran langsung (direct instruction) melalui media animasi berbasis macromedia flash terhadap minat belajar dan pemahaman konsep fisika siswa di SMA Plus Negeri 7 Kota Bengkulu. EXACTA, 10(1), 1-10.

Sarabando, C., Cravino, J. P., \& Soares, A. A. (2014). Contribution of a computer simulation to students' learning of the physics concepts of weight and mass. Procedia Technology, 13(2014), 112121.

https://doi.org/10.1016/j.protcy.2014.0 2.015

Saregar, A. (2016). Pembelajaran pengantar fisika kuantum dengan memanfaatkan media Phet simulation dan LKM melalui pendekatan saintifik: dampak pada minat dan penguasaan konsep mahasiswa. Jurnal Ilmiah Pendidikan Fisika Al-Biruni, 5(1), 53-60. https://doi.org/10.24042/jpifalbiruni.v5 i1.105

Serway, \& Jewett. (2014). Physics for scientists and engineers with modern physics. Stamford: Cengage Learning.

Setiawan, A. (2006). Pengantar metode numerik. Semarang: Andi.

Sudibjo, W. A. (2013). Penggunaan media pembelajaran fisika dengan e-learning berbasis Edmodo blog education pada materi alat optik untuk meningkatkan respon motivasi dan hasil belajar siswa di SMP Negeri 4 Surabaya. Jurnal Inovasi Pendidikan Fisika, 2(3), 187190.

Supardi, \& dkk. (2012). Pengembangan media pembelajaran dan minat belajar terhadap hasil belajar fisika. Jurnal Formatif, 2(1), 71-81.

Wahyudin, W., Sutikno, S., \& Isa, A. (2010). Keefektifan pembelajaran berbantuan multimedia menggunakan metode inkuiri terbimbing untuk meningkatkan minat dan pemahaman siswa. Jurnal Pendidikan Fisika Indonesia (Indonesian Journal of Physics Education), 6(1), 58-62. https://doi.org/10.15294/JPFI.V6I1.110 5

Wicaksono, D. S., \& Hakim, F. N. (2011). Media pembelajaran fisika interaktif bahasan kapasitor berbasis Flash dan XML. Journal Speed - Sentra Penelitian Engineering Dan Edukasi, 3(2), 47-54.

\section{PROFIL SINGKAT}

Hari Anggit Cahyo Wibowo lahir di Kabupaten Bangkalan, 28 Oktober 1989. Ia menyelesaikan Studi S1 tahun 2012 di Pendidikan Fisika, Universitas Negeri Malang dan Studi S2 tahun 2015 di Pasca Sarjana Institut Teknologi Bandung. Saat ini peneliti menjadi tenaga pendidik di Program Studi Pendidikan Fisika, STKIP Al Hikmah Surabaya. 